\title{
Functional expression of TLR9 in esophageal cancer
}

\author{
YANLI ZHANG ${ }^{1}$, QIUYAN WANG ${ }^{1}$, AILING MA $^{2}$, YUNHONG LI $^{1}$, RUI LI $^{1}$ and YIN WANG $^{1}$ \\ ${ }^{1}$ Basic Medical College, Center of Scientific Technology, Ningxia Medical University, Ningxia Key Laboratory of \\ Cerebrocranial Diseases; ${ }^{2}$ The General Hospital of Ningxia Medical University, Yinchuan, Ningxia 750004, P.R. China
}

Received January 22, 2014; Accepted February 28, 2014

DOI: $10.3892 / o r .2014 .3095$

\begin{abstract}
The Toll-like receptor 9 (TLR9) plays a crucial role in both innate and adaptive immune responses against infection and danger signals. Stimulation of TLR9 has been linked to invasion in various cancer cells in vitro. The present study evaluated the expression of TLR9 in human esophageal cancer (EC) cells and normal and malignant esophageal squamous epithelium, and examined the association between TLR9 expression, clinicopathological variables, and EC patient outcome. We further characterized the direct effects of TLR9 agonist $\mathrm{CpG}$ oligonucleotides (CpG ODN) and inhibitor chloroquine (CQ), on the proliferation and invasion of EC cells in vitro. RT-PCR, western blot, flow cytometry and immunohistochemical analysis were used to determine the expression of TLR9 in EC cell line TE10, and 90 cases of esophageal squamous cell carcinoma, including 30 cases of adjacent esophageal epithelium. The TLR9 expression was compared with tumor size, location, grade, stage and proliferation. We found basal expression of TLR9 in TE10 cells. Esophageal carcinomas exhibited TLR9 expression that was positively associated with tumor size, location and TNM stage $(\mathrm{P}<0.05)$. CpG ODN significantly enhanced the invasion of TE10 cells, which could be abrogated by a TLR9 inhibitor CQ. CpG ODN led to activation of NF- $\kappa \mathrm{B}$ and enhanced expression of matrix metalloproteinase (MMP)-2, MMP-7 and cyclooxygenase-2 (COX-2) mRNA. Expression of TLR9 in EC suggests a role of TLR9 related to cell proliferation and differentiation. Our findings indicate that TLR9 may represent a novel therapeutic target in this disease.
\end{abstract}

\section{Introduction}

Esophageal cancer (EC) is a highly malignant tumor and a major threat to health worldwide; it has a 5-year survival rate

Correspondence to: Professor Yin Wang, Basic Medical College, Center of Scientific Technology, Ningxia Medical University, Ningxia Key Laboratory of Cerebrocranial Diseases, 1160 Shengli Street, Yinchuan, Ningxia 750004, P.R. China

E-mail: yin-wang@hotmail.com

Key words: Toll-like receptor 9, esophageal cancer, CpG-oligonucleotides, chloroquine of $<10 \%$ and 300,000 people succumb to the disease, half of whom are from China. In China, EC is characterized by its distinct geographic distribution and differences in ethnic prevalence (1). Ningxia, in Western China, has one of the highest prevalence and mortality rates of esophageal carcinoma in the world. Despite advances in clinical treatment, the complexity of cancer has posed a formidable challenge to both clinicians and researchers. Due to its relapse and metastasis characteristics, prognostic factors are essential to improve the classic risk classification in EC.

Chronic infection and inflammation can induce cancer formation via proinflammatory factors by promoting angiogenesis and metastasis contributing to cancer development and growth. Toll-like receptors (TLRs) are pathogen recognizing receptors that mediate innate immune responses including the secretion of cytokines as well as the release of chemokines, thus limiting microbe spreading and triggering inflammatory responses (2-6). The TLR family consists of $>10$ members in humans. TLR9 is one of the important members in this family. Ligand binding to TLR9 activates several different signaling factors, such as nuclear factor $-\kappa \mathrm{B}(\mathrm{NF}-\kappa \mathrm{B})$ eventually characterized by increased production of inflammatory mediators (7). Recent studies found that high expression of TLR9 occurred not only in immune cells, but also in various cancer cells including breast, brain, ovarian, gastric, lung and prostate cancer cells (8). The role of TLR9 expressed by tumor cells in the evasion of immune surveillance was demonstrated in animal experiments showing that TLR9 stimulation may lead to tumor progression and inflammation and cell survival increasing (9). Furthermore, treatment of TLR9-expressing cancer cells with synthetic TLR9 ligands that are reminiscent of bacterial DNA increases the invasion of breast and prostate cancer cells in vitro (10). These findings may be useful in elucidating potential prognostic markers. However, currently, very little is known about the regulation of TLR9 expression and its actual role in EC cells.

The purpose of the present study was to investigate the expression of TLR9 in human EC cells and normal and malignant esophageal squamous epithelium and to analyze its possible association with EC invasion and prognosis. Therefore, we analyzed the protein levels of TLR9 by immunohistochemical techniques, western blotting, flow cytometric analysis. The mRNA levels of tumor progression and migrationrelated factors such as matrix metalloproteinase-2 (MMP-2), MMP-7 and cyclooxygenase-2 (COX-2) were examined by reverse transcription-polymerase chain reaction (RT-PCR). 
Furthermore, we performed MTT analysis and scratch assays to examine the direct effects of cytosine phosphate guanosine oligodinucleotide (CpG ODN), on tumor migration and the proliferation of tumor cells to further characterize the possible role of functional TLR9 expression in EC.

\section{Materials and methods}

Chemicals. The full phosphorothioated ODN 1816 (5'-TCCAT GACGTTCCTGACGTT-3') and primers were synthesized by SBS Genetech (Beijing, China). The mouse monoclonal antibodies against FITC-conjugated TLR9, TLR9, GAPDH, $\mathrm{NF}-\kappa \mathrm{B}$ and $\operatorname{IgG} 2 \alpha$ isotype control were purchased from Abcam (Beijing, China). Annexin V-FITC/PI kit was obtained from Bender (Shenzhen, China). TRIzol, RPMI-1640 and FBS were from Gibco (Shanghai, China). Chloroquine was purchased from Sigma-Aldrich (Shanghai, China). Reverse transcription kit was bought from TransGen Biotechnology (Beijing, China). BCA and ECL kit were from Pierce (Shanghai, China).

Cell culture. TE10 cells were cultivated in RPMI-1640 medium supplemented with $10 \%$ FBS, penicillin $(100 \mathrm{U} / \mathrm{ml})$ and streptomycin $(100 \mathrm{~g} / \mathrm{ml})$. Cells were maintained at $37^{\circ} \mathrm{C}$ in a humidified incubator gassed with $95 \% \mathrm{O}_{2}$ and $5 \% \mathrm{CO}_{2}$.

RNA extraction and RT-PCR analysis. Total RNA was extracted from TE10 cells by TRIzol. The purity and concentration of RNA was determined by spectrophotometry at 260 and $280 \mathrm{~nm}$. Complementary DNA (cDNA) was synthesized using a reverse transcription kit. Quantitative PCR was performed as follows: $94^{\circ} \mathrm{C}$ for $5 \mathrm{~min}, 35$ cycles of denaturation at $94^{\circ} \mathrm{C}$ for $30 \mathrm{sec}$, annealing at $62^{\circ} \mathrm{C}$ for $30 \mathrm{sec}$, and extension at $72^{\circ} \mathrm{C}$ for $30 \mathrm{sec}$, and a single extension at $72^{\circ} \mathrm{C}$ for $5 \mathrm{~min}$. Primers used for the PCR were: TLR9: sense, 5'-GGACA CTCCCAGCTCTGAAG-3' and antisense, 5'-TTGGCTG TGGATGTTGTTGT-3'; MMP2: sense, 5'-CTTCCAAGT CTGGAGCGATGT-3' and antisense, 5'-TACCGTCAAAGG GGTATCCAT-3'; MMP7: sense, 5'-CGGGGTACCATAATG TCCTGAATGATACC-3' and antisense, 5'-CCCAAGCTTT GCCGTCCAGAGACAATTG-3'; COX-2: sense, 5'-GCCTGA ATGTGCCATAAGACTGAC-3' and antisense, 5'-AAA CCCACAGTGCTTGACACAGA-3'; $\beta$-actin: sense, 5'-TGG CACCCAGCACAATGAA-3' and antisense, 5'-CTAAGT CATAGTCCGCCTAGAAGCA-3'. PCR products were applied to $1.5 \%$ agarose gel electrophoresis. The gel was scanned and the electrophoresis image was input into Kodak gel image analysis system.

Western blotting. Cells were washed with PBS three times and lysed with RIPA buffer. The protein concentration was determined with BCA kit according to the manufacturer's instructions. Equal quantities of protein were loaded and ran on SDS/polyacrylamide gels and then transferred to a PVDF membrane. Membranes were blocked with 5\% dried milk and incubated with primary antibody of TLR9 in TBST overnight at $4^{\circ} \mathrm{C}$. After rinsing in milk-TBST, blots were incubated in the horseradish peroxidase-conjugated secondary antibody. The expression of TLR9 was detected by using the enhanced chemiluminescence (ECL) detection system and X-ray films.
Flow cytometry. TE10 cells were detached with $0.05 \%$ trypsin/0.02\% EDTA and washed with cold PBS. For detection of TLR9 expression, cells were fixed and permeabilized using the Cytofix/Cytoperm kit according to the manufacturer's instructions. Mouse anti-human TLR9 $\mathrm{mAb}$ or the appropriate isotypic $\mathrm{IgG} 2$ a control $\mathrm{mAb}$ was performed at $0.5 \mathrm{mg} / 10^{6}$ cells for $30 \mathrm{~min}$ on ice. After washing with cold PBS, cells were stained with fluorescein (FITC)-conjugated anti-mouse IgG. Cells were analyzed with a BD FACSCalibur flow cytometer (BD Biosciences, San Jose, CA, USA) and gated using forward vs. side scatter to exclude dead cells and debris. Fluorescence of $10^{4}$ cells per sample was acquired in logarithmic mode for visual inspection of the distributions and in linear mode for quantifying the expression of the relevant molecules by calculating the mean fluorescence intensity with Cell Quest Pro software.

Cell viability assay. Cells were seeded and grown on sterile 96-well plates. The experimental cell concentration was $3 \times 10^{5} / 1$. Cells were pretreated with $10 \mu \mathrm{g} / \mathrm{ml} \mathrm{CpG} \mathrm{ODN} \mathrm{(TLR9}$ ligand) or CQ (TLR9 inhibitor) for $1 \mathrm{~h}$. Then, $10 \mu \mathrm{g} / \mathrm{ml} \mathrm{CpG}$ ODN were added to the cells and incubated for 12, 24 or $48 \mathrm{~h}$. Cell growth was then quantified using the MTT-based In Vitro Toxicology Assay kit. A value was measured in a microplate reader at the wavelength of $450 \mathrm{~nm}$ at $37^{\circ} \mathrm{C}$ incubated for $4 \mathrm{~h}$.

Enzyme-linked immunosorbent assay (ELISA). TE10 cells were treated with $20 \mu \mathrm{g} / \mathrm{ml} \mathrm{CpG} \mathrm{ODN} \mathrm{for} \mathrm{12,} 24$ and $48 \mathrm{~h}$. The supernatant was collected and the level of NF- $\mathrm{B}$ p65 in culture medium was quantified according to the manufacturer's directions. Absorbance was determined at $450 \mathrm{~nm}$ using a microplate reader.

Scratch/(wound-healing) assay. TE10 cellular suspension at a concentration of $5 \times 10^{5} / \mathrm{ml}$ was inoculated into a 6 -well culture plate at $2 \mathrm{ml}$ per well, and cultured for $24 \mathrm{~h}$. The medium was removed and replaced by $20 \mu \mathrm{g} / \mathrm{ml}$ of CPG ODN 1816 culture medium or CQ with a concentration of 100 or $200 \mu \mathrm{g} / \mathrm{ml}$ after the cells reached $80 \%$ confluence. The supernatant was discarded and a wound (scratch) was created. The wound was created in the confluent layer of cells using a sterile scraping cutter and the ability of cells to heal the wound was analyzed. The assays were documented using digital photography.

Tissue samples and patients. The project was reviewed and approved by the Ethics Committee of Ningxia Medical University. A total of 60 sections resected by radical operation for esophageal carcinoma, which were filed and randomly selected in the Department of Pathology, the General Hospital of Ningxia Medical University from March 1992 to September 2011. The other 30 sections from normal esophageal tissues as control were from the same patients undergoing esophageal surgery for the tumors but without cancer cell infiltration. After fixation in $10 \%$ formalin and embedding in paraffin, $5 \mu \mathrm{m}$ serial sections were made for each specimen.

Immunohistochemical analysis. Tissue sections were de-waxed, soaked in alcohol, and treated in antigen unmasking solution in the microwave for $10 \mathrm{~min}$ followed by incubation in $3 \%$ hydrogen peroxide for $10 \mathrm{~min}$ to inactivate endogenous 
A
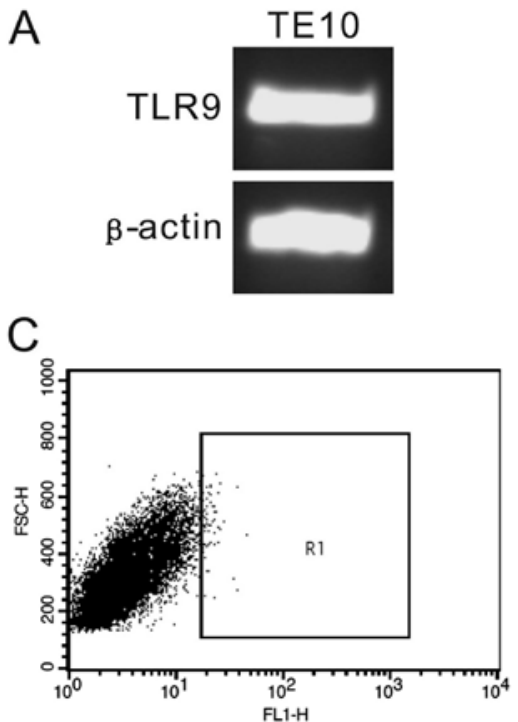

B
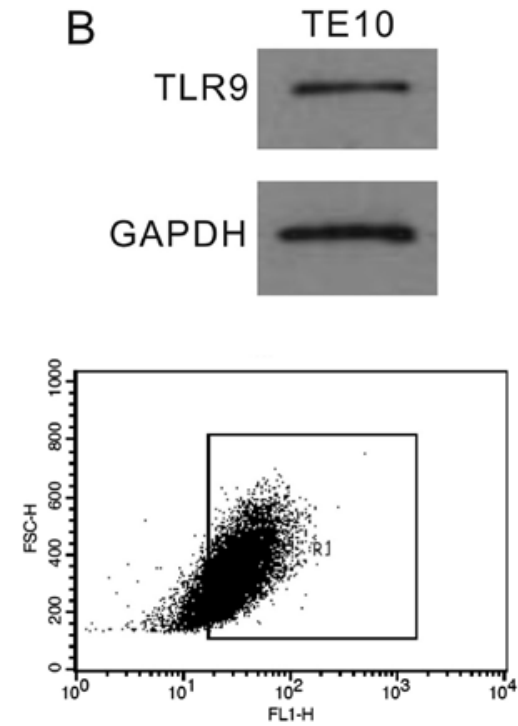

Figure 1. TLR9 expression in TE10 cells detected by RT-PCR, western blotting and flow cytometry experiments. (A) RT-PCR, (B) western blotting, (C) flow cytometry (left panel, IgG2a control; right panel, TLR9).

peroxidase activity. Sections were then incubated at $4^{\circ} \mathrm{C}$ overnight with anti-TLR9 (1:100 dilution) primary antibody. Immunostaining was performed by using the Histostain ${ }^{\mathrm{TM}}$ Plus kit according to the manufacturer's instructions.

Statistical analysis. All experiments were replicated at least three times on TE10 cells. All data are expressed as the means \pm SD. Data were analyzed by Student's t-test and one-way ANOVA, and statistical significance for comparison of means of different groups was calculated using LSD- $t$ analyses. $\mathrm{P}<0.05$ was considered to indicate a statistically significant difference.

\section{Results}

TLR9 expression in TE10 cells. The expression of TLR9 mRNA in EC cell line TE10 was analyzed by RT-PCR (Fig. 1A). The results revealed that TLR9 mRNA expressed in TE10 cells. To confirm the RT-PCR findings, we further examined the protein level of TLR9 in TE10 cells by western blotting (Fig. 1B) and flow cytometric analysis (Fig. 1C). We found that TLR9 protein was expressed in TE10 cells.

CpG ODN promotes TE10 cell growth. MTT assay was performed to investigate the effect of CpG ODN and CQ on the proliferation of TE10 cells. When cells were pretreated with $10 \mu \mathrm{g} / \mathrm{ml} \mathrm{CpG} \mathrm{ODN} \mathrm{or} 10 \mu \mathrm{g} / \mathrm{ml} \mathrm{CQ}$, and then treated with $10 \mu \mathrm{g} / \mathrm{ml} \mathrm{CpG} \mathrm{ODN} \mathrm{for} 12,24$ or $48 \mathrm{~h}$, the proliferation was significantly promoted compared with the control groups (Fig. 2). However, when cells were pretreated with TLR9 inhibitor CQ, the proliferation was not enhanced by $\mathrm{CpG}$ ODN .

CpG ODN promotes $N F-\kappa B$ p65 expression. Upon the recognition of CpG ODN, TLR9 recruits specific intracellular adaptor proteins such as NF- $\mathrm{kB}$ to initiate signaling pathways. The ELISA assay was performed to evaluate the activation

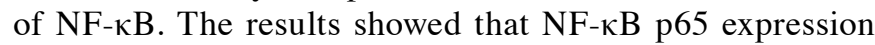

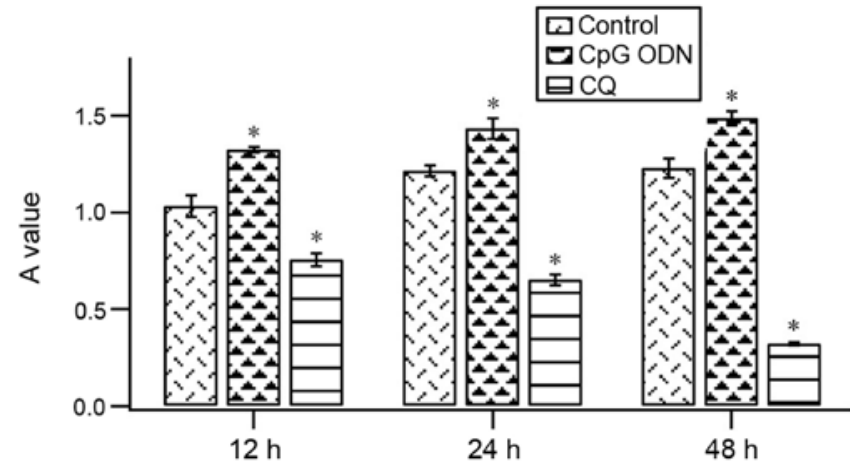

Figure 2. Effects of CpG ODN and CQ on cell viability of TE10 cells by MTT assay. Cells were pretreated with $10 \mu \mathrm{g} / \mathrm{ml} \mathrm{CpG} \mathrm{ODN} \mathrm{or} \mathrm{CQ} \mathrm{for} 1 \mathrm{~h}$, followed by treatment with $10 \mu \mathrm{g} / \mathrm{ml} \mathrm{CpG} \mathrm{ODN} \mathrm{for} 12,24$ or $48 \mathrm{~h}$. A value was measured in a microplate reader at the wavelength of $450 \mathrm{~nm}$. Results were obtained from three independent experiments. ${ }^{*} \mathrm{P}<0.01$ compared with control.

significantly increased at 12,24 and $48 \mathrm{~h}$ of treatment of cells with $20 \mu \mathrm{g} / \mathrm{ml} \mathrm{CpG} \mathrm{ODN} \mathrm{by} \mathrm{comparison} \mathrm{with} \mathrm{untreated} \mathrm{cells}$ indicating that $\mathrm{CpG}$ ODN activated NF- $\mathrm{kB}$ through the TLR9 signaling pathway (Fig. 3).

CpG ODN promotes MMP-2, MMP-7 and COX-2 mRNA expression. NF- $\mathrm{KB}$ activation leads to upregulation of the expression of many proinflammatory and apoptosis-related genes. Therefore, we investigated the effects of TLR9 on the gene expression of MMP-2, MMP-7 and COX-2 in TE10 cells treated with different concentrations of TLR9 ligand $\mathrm{CpG}$ ODN and inhibitor CQ. As shown in Fig. 4, the mRNA levels of MMP-2, MMP-7 and COX-2 were markedly increased in TE10 cells treated with CpG ODN, but were suppressed by CQ.

CpG ODN promotes TE10 cell migration. Cells scratch assay results showed that following $\mathrm{CpG}$ ODN treatment, cell 


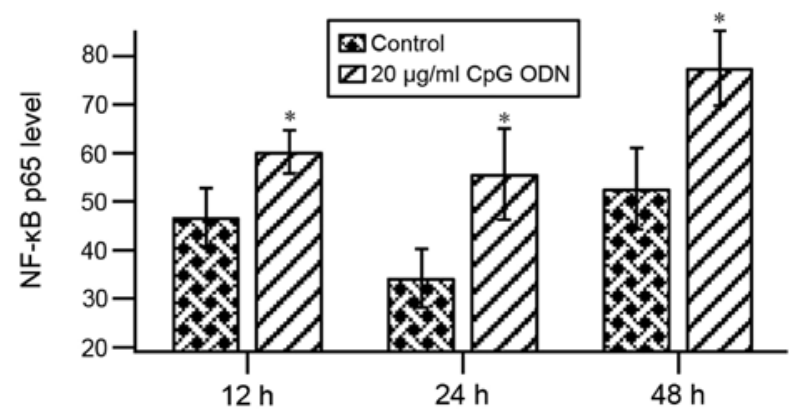

Figure 3. CpG ODN increases NF-кB p65 expression in TE10 cells measured by ELISA. Cells were treated with $20 \mu \mathrm{g} / \mathrm{ml} \mathrm{CpG} \mathrm{ODN} \mathrm{for} 12,24$ or $48 \mathrm{~h}$. Extracellular levels of NF- $\kappa \mathrm{B}$ p65 were measured using an ELISA assay. Results are representative of three independent experiments. ${ }^{*} \mathrm{P}<0.05$.
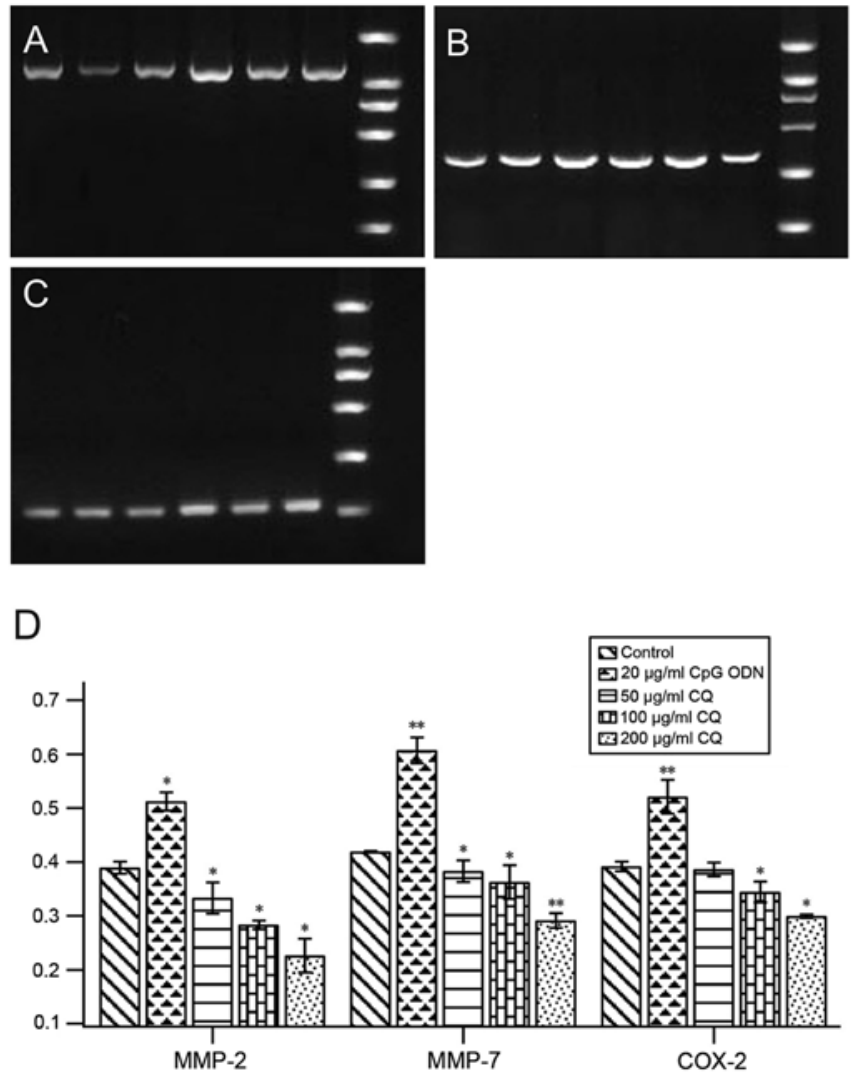

Figure 4. CpG ODN promotes mRNA levels of MMP-2, MMP-7 and COX-2 as detected by RT-PCR. (A) MMP-2, (B) MMP-7, (C) COX-2, (D) analyses of (A-C). From right: lane 1, marker; lane 2, $10 \mu \mathrm{g} / \mathrm{ml} \mathrm{CpG} \mathrm{ODN;} \mathrm{lane} \mathrm{3,}$ $20 \mu \mathrm{g} / \mathrm{ml} \mathrm{CpG} \mathrm{ODN;} \mathrm{lane} \mathrm{4,} 50 \mu \mathrm{g} / \mathrm{ml} \mathrm{CQ}$; lane 5, $100 \mu \mathrm{g} / \mathrm{ml} \mathrm{CQ;} \mathrm{lane} \mathrm{6,}$ $200 \mu \mathrm{g} / \mathrm{ml} \mathrm{CQ} .{ }^{*} \mathrm{P}<0.05,{ }^{* * *} \mathrm{P}<0.01$ compared with control.

migration to the damage zone increased and the migrated cell numbers after $48 \mathrm{~h}$ of treatment were markedly increased (Fig. 5A). However, CQ treatment inhibited TE10 cell migration (Fig. 5B and C).

TLR9 expression in human EC and its association with EC clinicopathological characteristics. The expression of TLR9 in human EC tissues was examined using immunohistochemical method. To determine the prognostic value of TLR9 protein for EC patients, we assessed 60 esophageal carcinoma
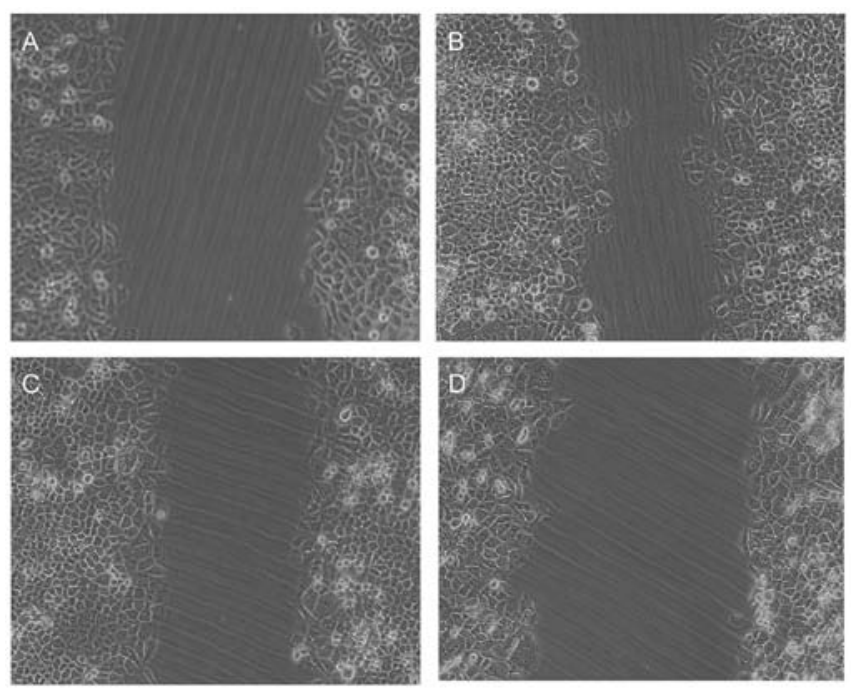

E

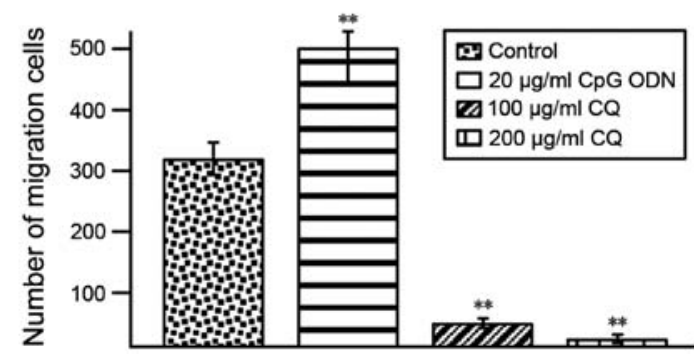

Figure 5. CpG ODN promotes TE10 cell migration by cell scratch assays. Cells were treated with $20 \mu \mathrm{g} / \mathrm{ml} \mathrm{CPG} \mathrm{ODN} \mathrm{or} 100 \mu \mathrm{g} / \mathrm{ml}$ or $200 \mu \mathrm{g} / \mathrm{ml} \mathrm{CQ}$ for $48 \mathrm{~h}$ and the supernatant was then abandoned and scratches were carried out in the center. A scratch was made in the confluent layer of cells using a sterile scraping cutter and the ability of cells to heal the scratch was analyzed. (A) Control, (B) $20 \mu \mathrm{g} / \mathrm{ml} \mathrm{CPG} \mathrm{ODN,} \mathrm{(C)} 100 \mu \mathrm{g} / \mathrm{ml} \mathrm{CQ,} \mathrm{(D)} 200 \mu \mathrm{g} / \mathrm{ml} \mathrm{CQ}$, (E) analyses of (A-D). ${ }^{*} \mathrm{P}<0.05,{ }^{* *} \mathrm{P}<0.01$ compared with control.

cases and 30 adjacent noncancerous tissues. Tissue sections were dewaxed and immunostained with anti-TLR 9 primary antibody. The results in Fig. 6 show that TLR9 expressed in both carcinoma tissues and adjacent noncancerous tissues. However, among 60 esophageal carcinoma tissues, TLR9 expression was found in 48 cases and the positive expression rate was $80 \%$. Among 30 adjacent noncancerous tissues, TLR9 expression was found in 17 cases and the positive expression rate was $56.7 \%$. The positive rate in carcinoma tissues was significantly higher than that in noncancerous tissues $(\mathrm{P}<0.05)$. TLR9 protein located mainly in the cytoplasm and cell surface (yellow and brown).

The clinicopathological analyses indicated that TLR9 expression in esophageal carcinoma was closely related to the degree of tumor differentiation, tumor size, location, and Tumor Node Metastasis (TNM) stage $(\mathrm{P}<0.05)$, and there was no significant association with age, gender, lymph node metastasis of patients $(\mathrm{P}>0.05)$ (Table I).

\section{Discussion}

The present study analyzed the significance of TLR9 expression in cultured esophageal tumor cells as well as esophageal carcinoma tissues. We demonstrated that high basal level of 
Table I. Statistical analysis of TLR9 expression and clinicopathological factors in esophageal carcinoma.

\begin{tabular}{|c|c|c|c|c|}
\hline Characteristics & Patients & TLR9 (+) n (\%) & $\chi^{2}$ & P-value \\
\hline Adjacent tissue control & 30 & $17(56.7 \%)$ & & \\
\hline Esophageal carcinoma & 60 & $48(80 \%)$ & 5.428 & 0.02 \\
\hline $\begin{array}{l}\text { Age } \\
\geq 60 \text { years } \\
<60 \text { years }\end{array}$ & $\begin{array}{l}38 \\
22\end{array}$ & $\begin{array}{l}29(76.3 \%) \\
14(63.6 \%)\end{array}$ & 1.103 & 0.294 \\
\hline $\begin{array}{l}\text { Gender } \\
\text { Male } \\
\text { Female }\end{array}$ & $\begin{array}{l}37 \\
23\end{array}$ & $\begin{array}{l}25(67.6 \%) \\
18(78.3 \%)\end{array}$ & 0.799 & 0.371 \\
\hline $\begin{array}{l}\text { Position } \\
\text { Upper esophagus } \\
\text { Lower esophagus }\end{array}$ & $\begin{array}{l}48 \\
12\end{array}$ & $\begin{array}{r}42(87.5 \%) \\
6(50.0 \%)\end{array}$ & 6.257 & 0.012 \\
\hline $\begin{array}{l}\text { Tumor size } \\
\geq 5 \mathrm{~cm} \\
<5 \mathrm{~cm}\end{array}$ & $\begin{array}{l}27 \\
33\end{array}$ & $\begin{array}{l}14(51.9 \%) \\
26(78.8 \%)\end{array}$ & 4.848 & 0.028 \\
\hline $\begin{array}{l}\text { Tumor metastases } \\
\text { Positive } \\
\text { Negative }\end{array}$ & $\begin{array}{l}19 \\
41\end{array}$ & $\begin{array}{l}14(73.7 \%) \\
23(56.1 \%)\end{array}$ & 1.699 & 0.192 \\
\hline $\begin{array}{l}\text { Tumor stage } \\
\text { I/II } \\
\text { III/IV }\end{array}$ & $\begin{array}{l}36 \\
24\end{array}$ & $\begin{array}{l}21(58.3 \%) \\
20(83.3 \%)\end{array}$ & 4.159 & 0.041 \\
\hline $\begin{array}{l}\text { Tumor differentiation } \\
\text { Well and moderately differentiated } \\
\text { Poorly differentiated }\end{array}$ & $\begin{array}{l}38 \\
22\end{array}$ & $\begin{array}{l}20(52.6 \%) \\
18(81.8 \%)\end{array}$ & 5.111 & 0.024 \\
\hline
\end{tabular}
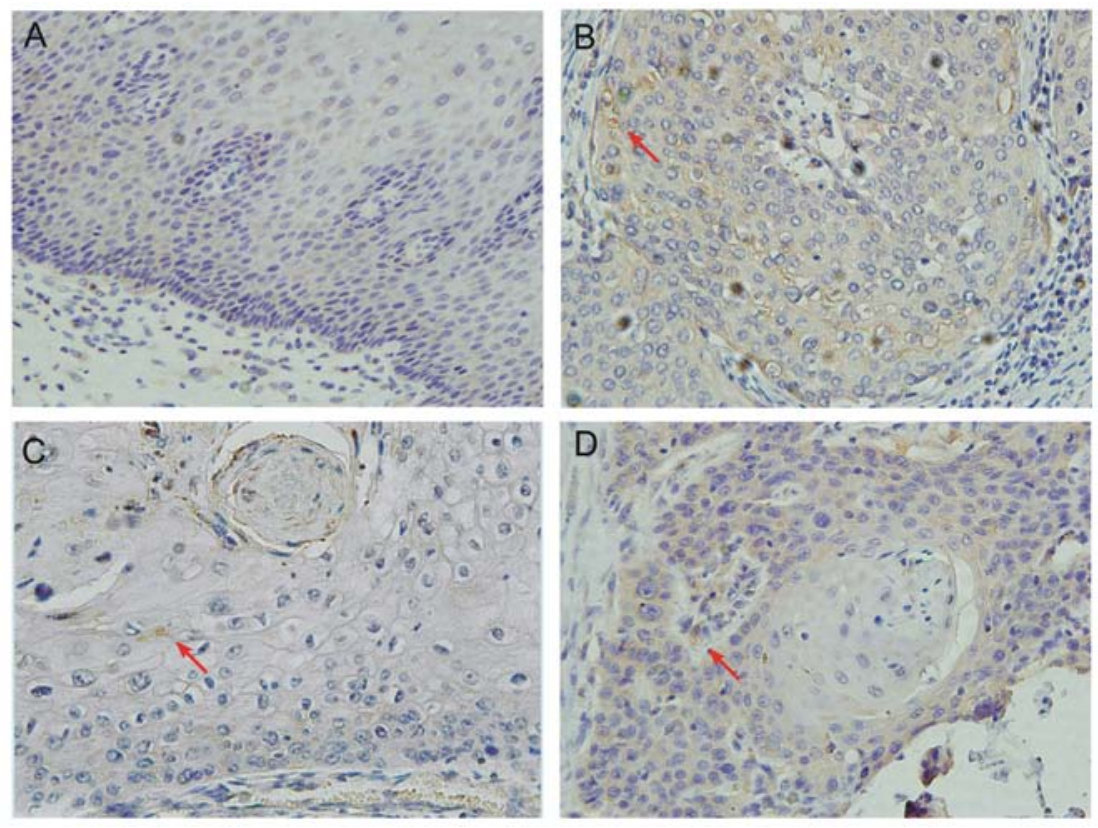

Figure 6. Immunohistochemical analyses of TLR9 expression in human EC tissues (10x40, yellow and brown, arrow). (A) Adjacent noncancerous tissues, (B) low differentiation EC tissue, (C) middle differentiation EC tissue, (D) high differentiation EC tissue.

TLR9 is present in the EC cell line, TE10, consistent with its overexpression and localization in esophageal carcinoma tissues, indicating an association of TLR9 expression with invasion and prognosis of EC.
TLR9 expression has been described in various cancer cell lines and different human tumors (8-11). To date, the association between TLR9 and clinicopathological parameters of cancer patients has not been widely evaluated. Tanaka et al 
demonstrated that cell surface stimulation of TLR9 promotes cell proliferation and survival in human hepatocellular carcinoma (12). TLR9 expression has been shown to be significantly higher in high grade gliomas compared to lowgrade gliomas (13). In breast cancer, it has been shown that the mRNA and protein levels of TLR9 significantly increased in recurrent breast carcinomas cells $(14,15)$. It has been reported that the gene of TLR9 is correlated with the invasive and metastatic potential of human pancreatic carcinoma (16). In lung cancers, TLR9 was found to express in a selection of human lung cancer tissues and various lung tumor cell lines (17). These findings suggest that high TLR9 expression and TLR9 signaling promote tumor growth, survival and immune evasion (18). Thus, in this study, we investigated the possible role of TLR9 in EC. Firstly, we measured the TLR9 expression in EC TE10 cells by western blotting, RT-PCR and flow cytometric techniques. The results from different methods showed that TLR9 expressed in TE10 cells. The results were consistent in three experiments. The MTT assay showed that CpG ODN could promote EC cell proliferation and TLR9 inhibitor CQ could suppress this effect of $\mathrm{CpG}$ ODN. In a scratch assay, TE10 cell migration to heal a scratched area on the plate surface was measured. The data showed that $\mathrm{CpG}$ ODN treatment markedly enhanced cell migration, but CQ treatment inhibited cell migration. The data suggest a role of TLR9 in EC cell proliferation and migration.

TLR9 recognizes the ODN with CpG motif. Accumulating data indicated that TLR9 agonist CpG ODN can promote tumor development and metastasis $(8-11,19)$. It has been proven that in TLR9 knockout mice, microbial DNA fragments cannot result in cancer invasion (20). It was also shown that the immunomodulating effect of natural and synthetic ODNs is mainly transmitted by TLR9 (21). After binding with CpG ODN, TLR9 signal pathway leads to the downstream activation of NF- $\kappa$ B and MAPK signaling pathways $(22,23)$, which may upregulate the expression of proinflammatory and apoptosisrelated genes. Thus, in this study, we investigated the effect of $\mathrm{CpG}$ ODN on NF- $\kappa \mathrm{B}$ expression in EC TE10 cells. We found that $\mathrm{CpG}$ ODN could markedly activate $\mathrm{NF}-\kappa \mathrm{B}$ p65 expression by comparison with untreated cells. The results indicated that CpG ODN activates the NF- $\mathrm{NB}$ signaling pathway by binding to TLR9 in EC cells.

Next, we examined the mRNA levels of three downstream genes of NF- $\kappa \mathrm{B}$ pathway upon $\mathrm{CpG}$ ODN treatment. MMPs are members of the neutral proteinase family. They were previously thought to be anti-fibrotic due to their ability to degrade and remodel of extracellular matrix. However, recent studies have shown that MMPs are implicated in tumor progression and migration (24-26). MMP-2 is a member of the metalloproteinase family, which degrades various components of the extracellular matrix (27). MMP-2 has been shown to be important in development and cell motility, and has an important role in cancer metastasis $(28,29)$. MMP-7 is a highly active MMP family member, which can activate other family members, such as MMP-2 and MMP-9, and play a central role in the degradation of the extracellular matrix (30). It also inhibits apoptosis of cancer cells, reduces cell adhesion and induces angiogenesis, making it easier for the cancer cells to invade small blood vessels and lymphatic tube and metastasize $(31,32)$. COX-2 has been extensively studied as an inducible expression protein and has been detected in various tumor tissues such as pancreatic cancer, colorectal carcinoma, non-small lung cancer positively correlates with tumor invasion and lymphatic metastasis $(33,34)$. We then detected the effects of CpG ODN and CQ on mRNA expression of MMP-2, MMP-7 and COX-2. The results showed that $\mathrm{CpG}$ ODN increased MMP-2, MMP-7 and COX-2 mRNA expression and CQ inhibited their expression as expected indicating that CpG ODN may bind to TLR9, and then activates NF- $\mathrm{B}$, so to upregulate MMP-2, MMP-7 and COX-2 gene expression. However, the actual roles of these three factors in EC require further study.

Lastly, the expression of TLR9 in human EC tissues was examined and its association with EC clinicopathological characteristics was analyzed. In the present study, TLR9 highly expressed in carcinoma tissues but weakly expressed in adjacent noncancerous esophageal tissues. Similarly, Droemann et al found TLR9 highly expressed in lung cancer cells but weakly expressed in adjacent noncancerous lung tissues (17). In esophageal carcinomas, extensive TLR9 expression was associated with high tumor grade and TNM stage, but not with age, gender, lymph node metastasis of patients. Extensive TLR9 expression and association with poor differentiation has also been noted in breast and prostate cancer, which is consistent with our results $(14,35)$. To date, there are very few reports on TLR9 expression in EC. Kauppila et al reported that high TLR9 expression was associated with poor differentiation, a high proliferation rate and increased TLR9 expression contributed to the growth and metastatic properties of esophageal adenocarcinoma (36). A study by Heikki et al showed that expression of TLR9 in the basal parts of normal esophageal epithelium related to cell proliferation and differentiation, and in dysplastic epithelium and in disseminated carcinomas indicated that TLR9 may serve as a novel marker for esophageal squamous dysplasia and carcinoma with metastatic potential (37).

In summary, we showed that TLR9 is highly expressed in cultured EC cells and in esophageal carcinoma tissues. $\mathrm{CpG}$ ODN could bind to TLR9 thus markedly activate NF- $\kappa$ B p65 expression and three cancer metastasis-related genes. In esophageal carcinomas, extensive TLR9 expression associated with high tumor grade and tumoral aggressiveness. Therefore, TLR9 might contribute to esophageal squamous cell carcinogenesis and may represent a suitable therapeutic target in EC. However, the mechanisms of the upregulation of TLR9 in esophageal malignancy require further investigation.

\section{Acknowledgements}

We thank all the members of the Immunology Laboratory for their help. This study was supported by Ningxia Natural Science Foundation Program (NZ11100); Fund of Ningxia Department of Education [(2010)297] and Ningxia Medical University Doctor Open Issue (KF2010-39). This study was also supported by the National Natural Science Foundation of China (grant nos. 31060140 and 31260243). The Project Sponsored by the Scientific Research Foundation for the Returned Overseas Chinese Scholars, State Education Ministry and the Program for New Century Excellent Talents in University (NCET), State Education Ministry for Dr Yin Wang. 


\section{References}

1. He J, Gu D, Wu X, Reynolds K, Duan X, Yao C, Wang J, Chen CS, Chen J, Wildman RP, Klag MJ and Whelton PK: Major causes of death among men and women in China. N Engl J Med 353: $1124-1134,2005$.

2. Fukata M and Abreu MT: Pathogen recognition receptors, cancer and inflammation in the gut. Curr Opin Pharmacol 9: 680-687, 2009.

3. Takeda K and Akira S: Microbial recognition by Toll-like receptors. J Dermatol Sci 34: 73-82, 2004.

4. Underhill DM: Toll-like receptors: networking for success. Eur J Immunol 33: 1767-1775, 2003.

5. Barton GM and Medzhitov R: Toll-like receptor signaling pathways. Science 300: 1524-1525, 2003.

6. Takeda K, Kaisho T and Akira S: Toll-like receptors. Annu Rev Immunol 21: 335-376, 2003.

7. Wagner H: The immunobiology of the TLR9 subfamily. Trends Immunol 25: 381-386, 2004.

8. Merrell MA, Ilvesaro JM, Lehtonen N, Sorsa T, Gehrs B, Rosenthal E, Chen D, Shackley B, Harris KW and Selander KS: Toll-like receptor 9 agonists promote cellular invasion by increasing matrix metalloproteinase activity. Mol Cancer Res 4: 437-447, 2006

9. Berger R, Fiegl H, Goebel G, Obexer P, Ausserlechner M, Doppler W, Hauser-Kronberger C, Reitsamer R, Egle D, Reimer D, Müller-Holzner E, Jones A and Widschwendter M: Toll-like receptor 9 expression in breast and ovarian cancer is associated with poorly differentiated tumors. Cancer Sci 101: 1059-1066, 2010.

10. Ilvesaro JM, Merrell MA, Swain TM, Davidson J, Zayzafoon M, Harris KW and Selander KS: Toll like receptor-9 agonists stimulate prostate cancer invasion in vitro. Prostate 67: 774-781, 2007.

11. Ren T, Xu L, Jiao S, Wang Y, Cai Y, Liang Y, Zhou Y, Zhou H and Wen Z: Tlr9 signaling promotes tumor progression of human lung cancer cell in vivo. Pathol Oncol Res 15: 623-630, 2009.

12. Tanaka J, Sugimoto K, Shiraki K, Tameda M, Kusagawa S, Nojiri K, Beppu T, Yoneda K, Yamamoto N, Uchida K, Kojima T and Takei Y: Functional cell surface expression of toll-like receptor 9 promotes cell proliferation and survival in human hepatocellular carcinomas. Int J Oncol 37: 805-814, 2010.

13. Wang C, Cao S, Yan Y, Ying Q, Jiang T, Xu K and Wu A: TLR9 expression in glioma tissues correlated to glioma progression and the prognosis of GBM patients. BMC Cancer 10: 415-426, 2010 .

14. Jukkola-Vuorinen A, Rahko E, Vuopala KS, Desmond R, Lehenkari PP, Harris KW and Selander KS: Toll-like receptor-9 expression is inversely correlated with estrogen receptor status in breast cancer. J Innate Immun 1: 59-68, 2008.

15. González-Reyes S, Marín L, González L, González LO, del Casar JM, Lamelas ML, González-Quintana JM and Vizoso FJ: Study of TLR3, TLR4 and TLR9 in breast carcinomas and their association with metastasis. BMC Cancer 10: 665-673, 2010.

16. Wu HQ, Wang B, Zhu SK, Tian Y, Zhang JH and Wu HS: Effects of CPG ODN on biological behavior of PANC-1 and expression of TLR9 in pancreatic cancer. World J Gastroenterol 17: 996-1003, 2011.

17. Droemann D, Albrecht D, Gerdes J, Ulmer AJ, Branscheid D, Vollmer E, Dalhoff K, Zabel P and Goldmann T: Human lung cancer cells express functionally active Toll-like receptor 9. Respir Res 6: 1-10, 2005.

18. Zeromski J, Mozer-Lisewska I and Kaczmarek M: Significance of Toll-like receptors expression in tumor growth and spreading: a short review. Cancer Microenviron 1: 37-42, 2008.

19. Jurk $\mathrm{M}$ and Vollmer J: Therapeutic applications of synthetic $\mathrm{CpG}$ oligodeoxynucleotides as TLR9 agonists for immune modulation. BioDrugs 21: 387-401, 2007.

20. Hemmi H, Takeuchi O, Kawai T, Kaisho T, Sato S, Sanjo H, Matsumoto M, Hoshino K, Wagner H, Takeda K and Akira S: A Toll-like receptor recognizes bacterial DNA. Nature 408: $740-745,2000$.
21. Takeshita F, Gursel I, Ishii KJ, Suzuki K, Gursel M and Klinman DM: Signal transduction pathways mediated by the interaction of $\mathrm{CpG}$ DNA with Toll-like receptor 9. Semin Immunol 16: 17-22, 2004

22. Kuo CC, Kuo CW, Liang CM and Liang SM: A transcriptomic and proteomic analysis of the effect of CpG-ODN on human THP-1 monocytic leukemia cells. Proteomics 5: 894-906, 2005.

23. Kostjuk S, Loseva P, Chvartatskaya O, Ershova E, Smirnova T, Malinovskaya E, Roginko O, Kuzmin V, Izhevskaia V, Baranova A, Ginter E and Veiko N: Extracellular GC-rich DNA activates TLR9- and NF- $\kappa \mathrm{B}$-dependent signaling pathways in human adipose-derived mesenchymal stem cells (haMSCs). Expert Opin Biol Ther 12 (Suppl 1): S99-S111, 2012.

24. Zhao H, Dong Y, Tian X, Tan TK, Liu Z, Zhao Y, Zhang Y, Harris DCh and Zheng G: Matrix metalloproteinases contribute to kidney fibrosis in chronic kidney diseases. World J Nephrol 2: 84-89, 2013.

25. Folgueras AR, Pendas AM, Sanchez LM and Lopez-Otin C: Matrix metalloproteinases in cancer: from new functions to improved inhibition strategies. Int J Dev Biol 48: 411-424, 2004.

26. Zeng ZS, Cohen AM and Guillem JG: Loss of basement membrane type IV collagen is associated with increased expression of metalloproteinases 2 and 9 (MMP-2 and MMP-9) during human colorectal tumorigenesis. Carcinogenesis 20: 749-755, 1999.

27. Bartsch JE, Staren ED and Appert HE: Matrix metalloproteinase expression in breast cancer. J Surg Res 110: 383-392, 2003.

28. Jezierska A and Motyl T: Matrix metalloproteinase-2 involvement in breast cancer progression: a mini-review. Med Sci Monit 15: RA32-RA40, 2009.

29. Sims JD, McCready J and Jay DG: Extracellular heat shock protein (Hsp)70 and Hsp90 alpha assist in matrix metalloproteinase-2 activation and breast cancer cell migration and invasion. PLoS One 6: e18848, 2011.

30. Lee KH, Shin SJ, Kim KO, Kim MK, Hyun MS, Kim TN, Jang BI, Kim SW, Song SK, Kim HS, Bae SH and Ryoo HM: Relationship between E-cadherin, matrix metalloproteinase-7 gene expression and clinicopathological features in gastric carcinoma. Oncol Rep 16: 823-830, 2006.

31. Okayama H, Kumamoto K, Saitou K, Hayase S, Kofunato Y, Sato Y, Miyamoto K, Nakamura I, Ohki S, Sekikawa K and Takenoshita S: CD44v6, MMP-7 and nuclear Cdx2 are significant biomarkers for prediction of lymph node metastasis in primary gastric cancer. Oncol Rep 22: 745-755, 2009.

32. Yeh YC, Sheu BS, Cheng HC, Wang YL, Yang HB and Wu JJ: Elevated serum matrix metalloproteinase-3 and -7 in $H$. pylorirelated gastric cancer can be biomarkers correlating with a poor survival. Dig Dis Sci 55: 1649-1657, 2010.

33. Sugie S, Tsukino H, Mukai S, Akioka T, Shibata N, Nagano M and Kamoto T: Cyclooxygenase 2 genotypes influence prostate cancer susceptibility in Japanese men. Tumour Biol: Nov 8, 2013 (Epub ahead of print).

34. Lu J, Li XF, Kong LX, Ma L, Liao SH and Jiang CY: Expression and significance of cyclooxygenase- 2 mRNA in benign and malignant ascites. World J Gastroenterol 19: 6883-6887, 2013.

35. Vaisanen MR, Vaisanen T, Jukkola-Vuorinen A, Vuopala KS, Desmond R, Selander KS and Vaarala MH: Expression of Toll-like receptor-9 is increased in poorly differentiated prostate tumors. Prostate 70: 817-824, 2010.

36. Kauppila JH, Takala H, Selander KS, Lehenkari PP, Saarnio J and Karttunen TJ: Increased Toll-like receptor 9 expression indicates adverse prognosis in esophageal adenocarcinoma. Histopathology 59: 643-649, 2011.

37. Heikki T, Kauppila JH, Soini Y, Selander KS, Vuopala KS, Lehenkari PP, Saarnio J and Karttunen TJ: Toll-like receptor 9 is a novel biomarker for esophageal squamous cell dysplasia and squamous cell carcinoma progression. J Innate Immun 3: 631-638, 2011. 